ently to-day and are inadequate to carry out both traditional Union functions and the newer functions which will become increasingly important. Secondly, they set out to consider practical steps by which reforms and improvements might be introduced.

Three main groups of problems are distinguished. First, those concerning the structure of the British Trade Union movement, such as the inefficiencies and difficulties arising from the existence of hundreds of autonomous Unions. Secondly, those concerning communication and control within individual Unions; and, thirdly, those concerning the Trades Union Congress itself, such as its weaknesses as a central co-ordinating body of the movement. The Broadsheet emphasizes that most of the problems examined do not exist everywhere, affecting some industries and some Unions much more than others: the whole Trade Unions movement is not to be condemned for the shortcomings of certain parts of it.

While the approach and diseussion are thoroughly realistic and include numerous constructive suggestions, it is pointed out that the final answers must come from those with direct experience and responsibility: the Broadsheet does not pretend to offer more than some contribution to a better understanding of the present issues and of some possible ways of reform and the likely obstacles. Nevertheless, it leaves no room for doubt that something more than tinkering with organization is required. A different economic system is already in the making and the real question is whether the prosent structure and practice of British Trade Unionism are such as to help or hinder the growth of a planned econornic system. None of those concerned can foresee how the process will develop, but that does not exempt any of them Government, industry, workers, financiers and economists -from the necessity of showing some foresight in guiding their particular steps with intelligence and purpose towards the common goal. In particular, it does not exempt the Trade Union movement from directing any changes in its present structure and practice into ways that would meet the evident needs of a planned system, so that in the process the movement may acquire its rightful and responsible part in shaping that new system. This implies that the Trade Union movement must take early steps to acquaint itself with the real facts of modern economic life and to disseminate that knowledge from the point of view of its own members' interests. Nor is a national planned policy possible with hundreds of Unions pulling different strings in different directions: to carry the weight and influence in national affairs to which it is entitled the movement must find ways of weaving those many strings into one powerful rope.

The Broadsheet is written with sympathy as well as insight and is a contribution to the informed discussion of current affairs which strengthens the hands of those Trade Union leaders who are already working for reform, and one for which the whole movement should be grateful.

\title{
FUTURE OF TOWN GAS
}

$\mathrm{T}$ OWN gas first originated from coal and it is now one hundred and fifty years ago that the first British commercial gas enterprise, the London and Westminster Gas Company, was founded. This concern established three gas-producing stations, laid initially fifteen miles of mains, was responsible for the first gas lamps on Westminster Bridge, and later, during the Victorian age, exercised much influence on the rapid expansion of the gas industry throughout Britain. The famous invention of the Welsbach incandescent gas mantle in 1887 revolutionized the efficiency of gas lighting everywhere, but this innovation came a little too late. The advent of electric lighting in 1882 sponsored a challenge to coal-gas as a source of lighting and heating which, although not fully appreciated at that time, was destined to win the battle for lighting, but certainly not for heating, for which purpose the use of gas has progressively increased. Between the First and Second World Wars the increasing competition from electricity determined radical changes in the gas industry which, by 1939, had become mainly a supplier for heating and cooking. Then came the Gas Act of 1948 which nationalized the entire industry, the basic pattern now clearly discernible, much as is the case with nationallized electricity as experienced to-day. The central controlling body is the Gas Council, appointed by the Ministry of Power, and in its annual report, surveying recent advances and new techniques of gas production, it states of the latter: "The most striking of these has been the rapid development and commercial application of the industry's research into the production of gaseous hydrocarbons by the hydrogenation and the reforming of petroleum oils".

The early process for making gas was by heating coal in iron or fire-clay retorts, and subject to many refinements evolved over the years this prineiple was followed for more than a century. The residual coke posed a problem until a process was developed whereby 'water gas' was manufactured; this depended on the chemical reaction set up by passing steam through beds of hot coke, resulting in decomposition of the steam into hydrogen and carbon monoxide; as the temperature fell, air was introduced into the system and more heat thus raised. Water gas produced by this eyclic action does not possess a high calorific value (about 300 B.Th.U. per cubic foot); it has to be enriched and this is achieved by the use of gas oil derived from petroleum. Gas oil is similar to Diesel oil in characteristics; it was originally called 'gas oil' because of its use in gas production. This form of enrichment resulted in a gas having about $500 \mathrm{~B}$.Th.U. per cubie foot, much the same calorifie value as gas manufactured direct from coal.

Further research on the complete gasification of coal, leaving nothing but ash, was commercially developed on the Continent after the end of the Second World War. According to an article in a recent issue of Esso Magazine (13, No. 1; Winter 1963-64), entitled "Gas from Oil": "One of the most successful methods of complete gasification is the Lurgi process in which coal is reacted with steam and oxygen. . . . This process is attractive because relatively poor quality coal can be gasified. But, again, the gas produced by the Lurgi method is not suitable for feeding directly into town gas distribution systems. It, too, has to be enriched by oil. . . . The real revolution in gas-making is not primarily a result of advances in making gas from coal but in making gas from oil'". Herein lies the crux of the present situation in the gas industry: its dependence more and more on the petroleum industry. Whereas in the past the only oil feedstock used in the gas industry was gas oil, nowadays feeding stocks include propane, butane, refinery gas, naphtha, and heavy fuel oils.

Since 1955 the gas industry has constructed some fifty plants for converting fuel oils into town gas. Although different types of plant are involved the basic processes used are similar and consist of passing steam and hydrocarbon vapours through a bed of hot catalyst whereby gas is produced. Further developments have resulted in the building of what are known as continuous catalytic conversion plants: that designed by Imperial Chemical Industries, Ltd., is stated in Esso Magazine to be smong the most efficient. But gas made from this proeess still has to be enriched. To give effect to this economically, a 
recent example is the Southern Gas Board's new installation of continuous catalytic conversion plant at Hythe, Hampshire. This is next door to the Esso Petroleum Company's refinery at Fawley. ". . . when it is commis. sioned early in 1964 it will, in fact, draw all the materials necessary to produce about 35 million cubic feet of gas a day from the refinery. Using the I.C.I. type of plant it will steam-reform naphtha and enrich it with refinery gas. Each year the Hythe works will take about 60,000 tons of naphtha and 23 million therms of refinery gas."

Substantial quantities of naphthe and liquefied petroleum gases are being supplied for the same purpose to other Gas Boards in Britain. In the case of the Scottish Gas Board's new works at Provan, Glasgow, the plant when fully in commission will have a capacity of about 50 million cubic feet of gas per day, involving supplies of more than 100,000 tons of naphtha and 80,000 tons of liquefied petroleum gases a year.

Thus until comparatively recently the oil industry supplied less than one-tenth of the feed-stock required for the production of town gas. To-day it supplies more than one-quarter of the raw material necessary. It is calculated that by 1967 the petroleum industry will be responsible for more than half the raw materials needed for Britain's entire gas supply. It may even be more if natural gas is included, for example, from the Sahara. Should success attend present explorations of the North Sea bed for oil or natural gas or both, especially within British territorial waters, then looking ahead to, say, 1975 , ". . . it seems highly probable that, together, oil and natural gas will be indirectly supplying about ninetenths of the nation's town gas". H. B. Mruner

\title{
THE TWO BIOLOGIES
}

I his inaugural lecture before the University of Oxford I On October 24, 1963, now published under the title The Two Biologies*, Prof. J. W. S. Pringle distinguishes between the consideration of how organisms came to be what they are and what functions their parts have in relation to the whole, and the analysis of what existing organisms are and how what they and their parts do can be described in terms of chemistry and physics. These are his two biologies, and while he thinks much of the present excitement derives from the promise which the second, analytical biology, is thought to hold for a fuller understanding of the nature of life, he examines the relation of biology to the rest of natural science and its present status in the intellectual endeavour of mankind. $\mathrm{He}$ argues that we have now to consider not only the philosophy of biology, but also the biology of philosophy. We are approaching the point when it is possible to investigate the types of thought process which go on in the human mind and determine the way in which we think and reason. $\mathrm{He}$ suggests that it is only by accepting a relativistic philoso-

The Two Biologies. (An Inaugural Lecture delivered before the University of Oxford on 24 October, 1963.) Pp. 28. By Prof. J. W. S. Pringle. (Oxford: Clarendon Press; London: Oxford University Press, 1963.) 3s. 6d. net. phy, in which man surrenders the vantage point from which he has claimed to be able to look out on the world, that he will achieve real consistency.

Prof. Pringle does not suggest that the new era in biology is to be identified as a replacement of the evolutionary biology by the new molecular biology: they are complementary within a host of branches of biology. This he illustrates by examples of the procedure of both biologies. After stressing that the dynamic equilibria in biology are not identical with the dynamical equilibria of statistical mechanics, he points out that organization of living organisms can preserve a fixed hierarchy. Hence the dynamically stable systems at one level survive to form the units which generate the next level, and so a progressive development can occur over a long period. This fixation depends on the existence of a particular type of chemical molecule in the cell-desoxyribonucleic acid. In the study of animal behaviour there has also to be a hierarchy of explanation, and from this he goes on to argue that biology must be extended to include the study of understanding and explanation. From this philosophical point of view he finds that biology provides both a magnificent framework for intellectual endeavour and a most satisfying way of life.

\section{STRONTIUM-90 AND C/ESIUM-I37 IN MILK AT ISPRA, ITALY, DURING 1960-62}

\author{
By M. De BORTOLI, P. GAGLIONE, Dr. A. MALVICINI and E. VAN Der STRICHT \\ Service de Protection, Section Site et Météorologie, C.C.R., Euratom, Ispra, Italy
}

\begin{abstract}
CINOE January 1960 routine analyses of the radio$S$ activity of samples of milk have been included in the programme of the environmental monitoring group of the Euratom Nuclear Research Centre at Ispra, Italy. Samples are taken monthly from four local dairies; in addition, regular checks are made of milk produced in an extensive zone of irrigated pastures east of Milano and sold in this city.
\end{abstract}

All samples are controlled for $\gamma$-activity with a multichannel $\gamma$-spectrometer and analysed for radiostrontium.

We shall limit ourselves in this article to report the results obtained and to make some comments with regard to the so-called 'observed ratio' (S.U. milk/S.U. diet), the ratio S.U./K.U. (that is, $\frac{\text { pc. }{ }^{90} \mathrm{Sr} / \mathrm{g} \mathrm{Ca}}{\mathrm{pe} .{ }^{137} \mathrm{Cs} / \mathrm{g} \mathrm{K}}$ ) and the relative contributions of the direct and indirect contamination of grass to the radioactivity of milk by means of the ${ }^{89} \mathrm{Sr}$ ${ }^{90} \mathrm{Sr}$ ratio. Details concerning the methods of analysis and of measurement are described in Euratom Report EUR $294 i$ together with the complete set of experimental results.

Figs. 1 and 2 show the fluctuations of the radioactivity due to strontium-90 and cæsium-137 in milk both for the Milano zone and the villages surrounding the Centre. Results are given as pe. ${ }^{90} \mathrm{Sr} / \mathrm{g} \mathrm{Ca}$ and pc. ${ }^{137} \mathrm{Cs} / \mathrm{g} \mathrm{K}$.

It is at once evident that, although the trend is quite similar, the activity in the immediate vicinity of the Centre is more than twice that of the Milano area. The reason for this should be sought in the difference in geographical and meteorological conditions between the two areas. Precipitation is nearly double at Ispra $(1,900 \mathrm{~mm} /$ year against $900 \mathrm{~mm} /$ year) and the pastures of the area have a low productivity. 